\title{
Thermal Environment Accuracy Investigation of Integrated Environmental Solutions-Virtual Environment (IES-VE) Software for Double-Story House Simulation in Malaysia
}

\author{
Maryam Qays Oleiwi, Mohd Farid Mohamed, Mohd Khairul Azhar Mat Sulaiman, \\ Adi Irfan Che-Ani and Sudharshan N. Raman \\ Universiti Kebangsaan Malaysia, Bangi, Malaysia
}

\begin{abstract}
In recent years, numerous simulation softwares have been created, upgraded and being used for building thermal performance. Integrated Environmental Solutions-Visual Environment (IES-VE) is considered as one of the common thermal performance simulation programs. This study discusses the investigation on the accuracy of IES-VE Software in simulating indoor thermal environment of a double-story house in Bangi, Malaysia by comparing with on-field measurement. Air temperature, relative humidity and mean radiant temperature have been selected as the main variables to assess the thermal environment. The on-field measurements were carried out by using $\Delta \Omega H D 323$ WBGT-PMV (indoor measurement) and MK-III Weather Stations ${ }^{\mathrm{TM}}$ (outdoor measurement). The results reveal that the differences between the on-field and simulation measurements were in the acceptable range which is $10-20 \%$. Therefore, the simulated data are valid and accurate for further thermal performance prognosis study for the tested building. The results in this study also agree well with those of other researchers.
\end{abstract}

Key words: IES-VE, thermal performance, simulation software, validation, WBGT-PMV, MK-III

\section{INTRODUCTION}

In tropical region which is typically distinguished by high temperature and relative humidity and low air velocity, the opportunity of perceiving thermal comfort for the occupants inside low-rise residential buildings is difficult. Thermal comfort can be defined as "a condition of the mind which expresses satisfaction with thermal environment" (Fanger, 1972). Therefore, people are resorted to use electrical air-conditioning devices. The increment of using air-conditioning devices to provide acceptable thermal comfort results in the increment of energy usage and electricity cost to the occupants in a hot and humid climate such as Malaysia (Sabarinah and Ahmad, 2005). In Malaysia, using air-conditioning devices has raised from 13,000 units in 1970-250,000 units in 1991 and the number of air conditioners is likely to rise to about 1.5 million units by 2020 UNDP. (2006). According to Malaysia Energy Information Hub MEIH (2015) the energy consumption in residential buildings in Malaysia increased dramatically in the recent years. Al-Mofleh et al. (2009) reported that $48 \%$ of all electricity consumption in Malaysia came from the commercial and residential buildings. Thus, achieving thermal comfort inside residential buildings with minimal energy consumption is highly required.
This is a preparatory study as a part of future thorough research that deals with simulating best materials to enhance the indoor thermal environment for low-rise housing in Malaysia. The aim of this study is to validate the simulated data of Integrated Environmental Solutions-Visual Environment (IES-VE) Software with the on-field measurement data. The simulation permits the utilization of easy change in material types, thicknesses and dimensions for all house components (roof, ground and walls). This contributes in manipulating house wall and roof materials to detect the optimum thermal performance. IES-VE Software has been approved by the US Energy Department as one of the 20 common building energy simulation programs as it includes dynamic thermal simulation tool (ApacheSim) which is also approved by the ASHRAE Standard 140 (Attia and De Herde, 2011). Additionally, ES-VE Software was validated and adopted by other researchers as Annan et al. (2016) by Pollock et al. (2009) and Ben and Steemers (2014) ENREF_1 in the UK for similar studies. Nevertheless, it is very crucial for the researchers to validate the simulation performance with the climate condition of tropics of Malaysia. However, the study of Nikpour et al. (2013) and Leng et al. (2012) have been conducted in the tropical climate of Malaysia but the first study, validated the software in term of heat gain while the second study, 
validated air temperature and relative humidity for one zone. The current study will be more comprehensive as it will validate three variables that's to say air temperature, relative humidity and mean radiant temperature for three rooms. None of previous studies included these three variables or validate for three indoor spaces.

Malaysian weather: Malaysia is an equatorial country that is situated at $2^{\circ} 30^{\prime} \mathrm{N}$ and $112^{\circ} 30^{\circ} \mathrm{E}$. The typical lineaments of Malaysian climate are uniform temperature, high humidity and profuse precipitation (MMD, 2010). In most locations, the maximum relative humidity is between 80,88 and $90 \%$ in the high land areas and the minimum is $60 \%$. The mean maximum day time temperature is $29-32^{\circ} \mathrm{C}$ while the minimum temperature is $22-24^{\circ} \mathrm{C}$ with a rain fall of $1000 \mathrm{~mm}$ per year (Sabarinah and Ahmad, 2005). These characteristics of Malaysian climate is suspected as a major factor for thermal discomfort. Therefore, there is a constant need for design and devices to accomplish indoor thermal comfort.

According to Malaysian Meteorological Department MMD (2010) Malaysia receives high solar radiation and about $12 \mathrm{~h}$ of sunshine per day. Solar radiation and heat gain that are absorbed by building envelope such as roof, wall, window and floor are considerable factors as they can be converted into heat inside the building and influence the indoor thermal comfort. Subsequently, the cooling load of the building increases.

Although, the wind over Malaysia is commonly light and varies, there are some uniform periodic variations in the wind flow patterns. Depending on these variations, two main seasons can be recognized in particular, the Southwest monsoon and Northeast monsoon. Also, there are two shorter periods of inter-monsoon seasons in April and October. The Southwest monsoon season generally, begins in May and ends in September. The Northeast monsoon season frequently starts in early November and stops in March. The average ambient temperature recorded is consistently high (between 27 and $33^{\circ} \mathrm{C}$ ). The average daily global solar radiation in Malaysia is 4500 $\mathrm{kWh} / \mathrm{m}^{2}$ (Anonymous, 2014).

Another typical characteristic of Malaysia is the abundant rainfall especially, during the Northwest monsoon. In general, the climatic conditions of Malaysia are almost uniform for all states as reported by Malaysian Meteorological Department (MMD, 2010).

\section{MATERIALS AND METHODS}

Field measurements: The on-field measurements were conducted at Universiti Kebangsaan Malaysia, Bangi, which is located $27 \mathrm{~km}$ from Kuala Lumpur, the capital city

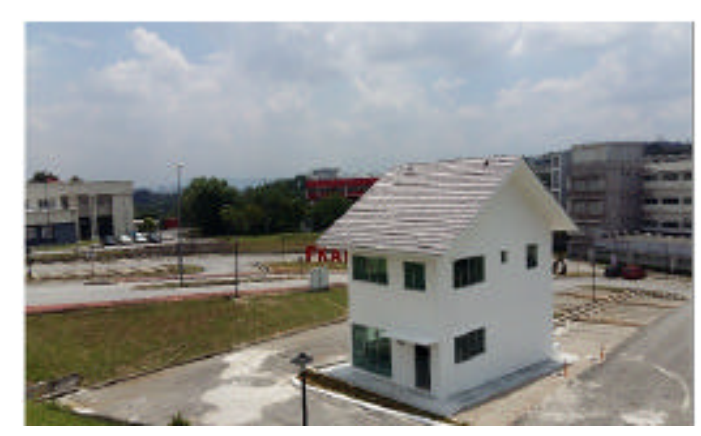

Fig. 1: The house used for on-field measurements

of Malaysia. The building is a double-story house, built using common construction building materials (sand brick and cement for the walls and concrete roof tiles for the roof). The building was purposely built for the research activities and imitated the terrace house (end-lot unit) which is the common typology for house in Malaysia.

The house includes a living room, kitchen and bathroom on the ground floor and three bedrooms and two toilets on the first floor. In this study, room 1 refers to the living room, room 2 refers to the second bedroom and room 3 refers to the master bedroom. The house was kept empty without furniture to decrease the thermal transactions among objects. The windows of the living room and master bedrooms are facing West and North. The windows of the kitchen and the second bedrooms are facing East and North as shown in Fig. 1 which also shows the surrounding conditions.

The instruments used in this study were: Three sets of $\Delta \Omega H D 32.3$ WBGT-PMV with data logger were placed indoor, at the center of the living room (room 1), the secondary bedroom (room 2) and the master bedroom (room 3). The third bedroom was not investigated. The data logger was positioned at $1.5 \mathrm{~m}$ above the ground to record the values of air Temperature (Ta), Relative Humidity $(\mathrm{RH})$ and mean radiant Temperature $(\mathrm{Tr})$ in each room. Then, the data for each room were recorded using the Software DeltaLog10 Version 1.30. Figure 2 shows the position of each instrument inside the house.

A MK-III Weather Stations ${ }^{\mathrm{TM}}$ was set up nearby the house at $2 \mathrm{~m}$ above the ground to collect the surrounding environmental conditions which included air temperature, relative humidity and rainfall. The data were obtained using the Software Weather View 32.

All the instruments were calibrated carefully before any measurements to provide reliable results and to correct for the offset on the readings. The instruments were set to record data at $10 \mathrm{~min}$ intervals for $24 \mathrm{~h}$. The selected measurement periods were from 23 April to 10 
(a)
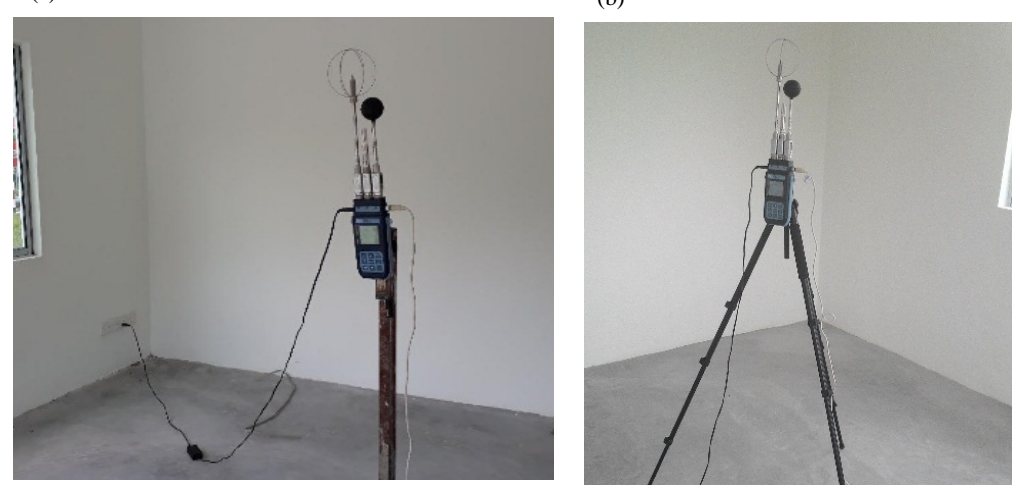

(d)

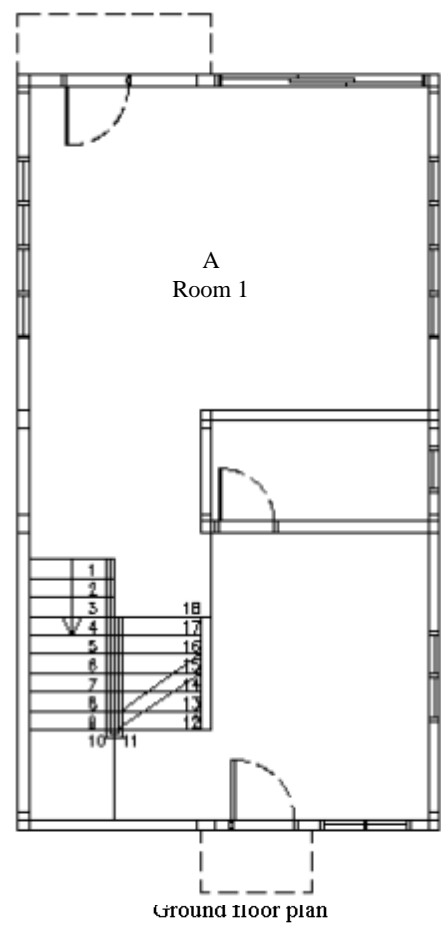

(e)

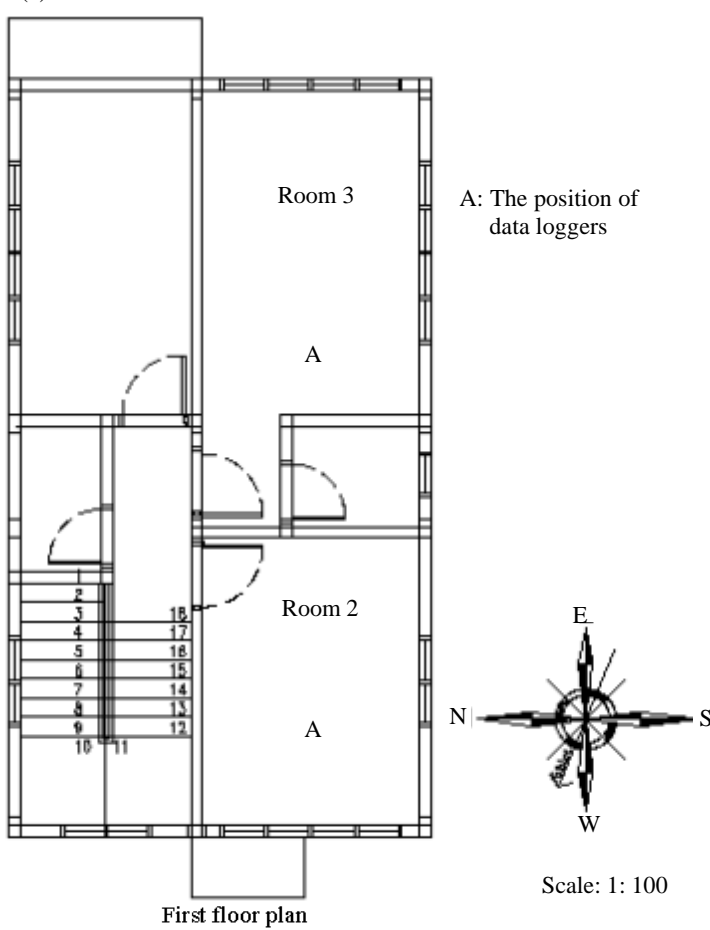

Fig. 2: The positions of the instruments inside the house: a) Data logger instruments in Room1; b) Data logger instruments in Room2; c) Data logger instruments in Room3; d) Ground floor and e) First floor

May, 2017 which is considered as the hottest months in Malaysia according to Malaysian Meteorological Department MMD (2010) and Sulaiman (2017) on the basis of the average monthly data of temperature for 11 years.

Black globe temperature was also measured by the instrument of $\Delta \Omega H D 32.3 \mathrm{WBGT}-\mathrm{PMV}$, that could provide the value of mean radiant Temperature (Tr) simultaneously. Mean radiant temperature is defined as "the uniform temperature of an imaginary black enclosure in which an occupant would exchange the same amount of radiant heat as in the actual non-uniform enclosure" (Atmaca et al., 2007).

(c)

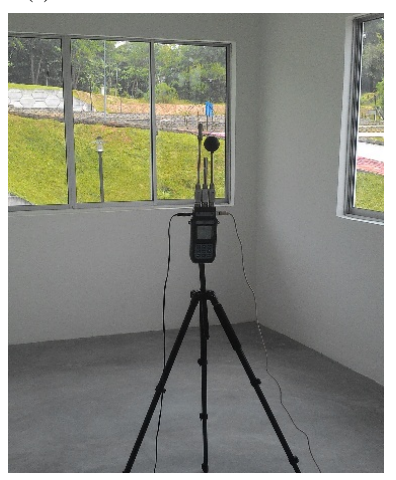


Simulation: The geometry of the computational model for the tested house was created using IES-VE (2015) Software. Then, the building geometry and dimension, fabric materials, window types and opening profile, building orientation and simulation time were applied to the model. The location of the house was defined by IES-VE [APlocate] which was set as Kuala Lumpur suburbs as it is the nearest to the site. Window openings profile were defined as closed all the time as this was the situation of the windows during the data collection period. The main simulation outputs obtained from IES-VE were indoor and outdoor air temperatures, relative humidity and mean radiant temperature of each case. The results were converted into Excel sheets to facilitate the data analysis.

Validation: To validate the accuracy of the IES-VE software, the simulated indoor thermal conditions obtained by the software and by on-field measurements were compared by analyzing the percentage difference between the two measurements. The Percentage Difference (PD) between the simulated measurements (SM) and on Field Measurements (FM) for the indoor thermal conditions was calculated by using Eq. 1:

$$
\begin{aligned}
& \mathrm{PD}=\frac{(\mathrm{SM}-\mathrm{FM})}{\mathrm{FM}} \times 100 \mathrm{PD}= \\
& (\mathrm{SM}-\mathrm{FM}) \mathrm{FM} \times 100
\end{aligned}
$$

The study of Maamari et al. (2006) proposed that the acceptable percentage difference between the on-field and simulation measurements is $10-20 \%$. In spite of the study used Complex Fenestration Systems (CFS) as simulation tool for daylight simulation, other studies like Leng et al. (2012) and Nikpour et al. (2013) have agreed with the same percentage to be a reference for them for validating air temperature, relative humidity and heat gain of IES-VE Software, respectively. The reason for that is the overall goal of Maamari et al. (2006) study was to determine whether an agreement between simulation algorithmic approach and on-field measured method was good enough to guide to easier and valuable practical design analyses. Therefore, the same range of $10-20 \%$ will be considered for this study as a benchmark for IES-VE validation.

\section{RESULTS AND DISCUSSION}

The results of the same parameters monitored during the on-field measurements were calculated. The chosen simulation period was 23 April to 10 May 2017 as it was the same period for the on-field measurements. Figure 3

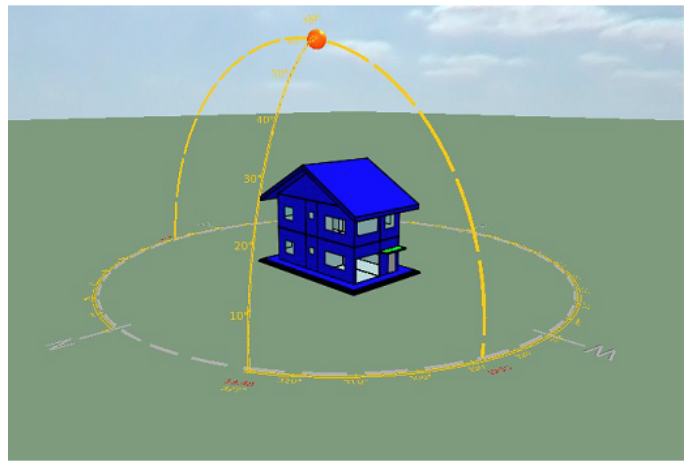

Fig. 3: The tested house in simulated in the IES-VE Software

shows the tested house modeled using the IES-VE Software. Table 1 shows the highest and lowest percentage differences between the results for the three rooms for 7 days.

The IES-VE simulation results were compared with the on-field measurement data. The on-field measurements of the indoor air temperature in room 1 show that the highest air temperature recorded was $34.9^{\circ} \mathrm{C}$ on 23 April 2017 at $1535 \mathrm{~h}$ while the simulation results for room 1 show that the highest indoor air temperature was $34.52^{\circ} \mathrm{C}$ on the same day at $1635 \mathrm{~h}$. The discrepancy of the highest temperature recorded by the on-field experiment and simulation in the same day is $1.1 \%$ and the time differences is only $1 \mathrm{~h}$. The discrepancy range is considered acceptable, since, the percentage of difference is $<10-20 \%$. For the on-field experiments, the lowest indoor air temperature in room 1 was $27.9^{\circ} \mathrm{C}$ at $0605 \mathrm{~h}$ on 27 April 2017 while the lowest simulated temperature was $26.26^{\circ} \mathrm{C}$ at $0735 \mathrm{~h}$ on 30 April 2017. The deviation of the IES-VE result of $5.9 \%$ is still within the acceptable range. The time differences between the two results is $1 \mathrm{~h}$ and $30 \mathrm{~min}$. Furthermore, the time recorded in the on-field experiment and simulation for the highest and lowest temperatures are similar.

The highest indoor relative humidity of $84.1 \%$ in the on-field measurements for room 1 was achieved at $0405 \mathrm{~h}$ on 30 April 2017. Meanwhile, the maximum indoor relative humidity for room 1 obtained from the IES-VE simulation was $92.3 \%$ at 0745 h on 27 April 2017. Similar, to the air temperature case, the discrepancy of the maximum data of the relative humidity is $9.7 \%$ which is still under the acceptable range. Furthermore, the maximum data for both on-field experiments and simulation were happened in the time difference of approximately $3 \mathrm{~h}$ in the morning. For the minimum indoor relative humidity, the on-field experiments recorded $61.7 \%$ as the lowest value on 23 
Table 1: The highest and lowest percentage difference between the simulation and on-field measurement results for room 1-3

\begin{tabular}{|c|c|c|c|c|c|c|c|c|c|c|}
\hline \multirow[b]{2}{*}{ Days } & \multirow[b]{2}{*}{$\begin{array}{l}\text { Percentage } \\
\text { difference }\end{array}$} & \multicolumn{3}{|c|}{ Air temperature } & \multicolumn{3}{|c|}{ Relative humidity } & \multicolumn{3}{|c|}{ Mean radiant temperature } \\
\hline & & $\begin{array}{c}\text { Room } 1 \\
(\%)\end{array}$ & $\begin{array}{c}\text { Room } 2 \\
(\%)\end{array}$ & $\begin{array}{c}\text { Room } 3 \\
(\%)\end{array}$ & $\begin{array}{l}\text { Room } 1 \\
(\%)\end{array}$ & $\begin{array}{c}\text { Room } 2 \\
(\%)\end{array}$ & $\begin{array}{c}\text { Room } 3 \\
(\%)\end{array}$ & $\begin{array}{c}\text { Room } 1 \\
(\%)\end{array}$ & $\begin{array}{c}\text { Room } 2 \\
(\%)\end{array}$ & $\begin{array}{c}\text { Room } 3 \\
(\%)\end{array}$ \\
\hline 1 & $\begin{array}{l}\text { Highest } \\
\text { Lowest }\end{array}$ & $7.3-7.1$ & $2.6-13.7$ & $3.3-7.4$ & $11.6-19.0$ & $19.6-14.4$ & $13.0-16.9$ & $9.4-6.19$ & $5.2-15.5$ & $5.4-6.6$ \\
\hline 2 & $\begin{array}{l}\text { Highest } \\
\text { Lowest }\end{array}$ & $8.1-9.4$ & $4.2-17.3$ & $4.9-10.2$ & $14.4-19.4$ & $18.9-19.4$ & $18.2-17.7$ & $10.5-8.6$ & $6.8-18.8$ & $6.9-9.7$ \\
\hline 3 & $\begin{array}{l}\text { Highest } \\
\text { Lowest }\end{array}$ & $7.9-4.9$ & $4.2-5.8$ & $6.2-5.7$ & $14.2-17.5$ & $18.3-12.1$ & $15.6-13.6$ & $9.4-10.1$ & $6.5-5.4$ & $6.6-5.4$ \\
\hline 4 & $\begin{array}{l}\text { Highest } \\
\text { Lowest }\end{array}$ & $5.8-10.6$ & $1.1-13.7$ & $2.3-10.6$ & $11.0-17.4$ & $19.3-11.2$ & $16.6-14.0$ & $8.4-10.1$ & $4.0-14.2$ & $4.3-9.5$ \\
\hline 5 & $\begin{array}{l}\text { Highest } \\
\text { Lowest }\end{array}$ & $7.2-9.5$ & $2.1-16.9$ & 4.2-10.3 & $19.8-13.5$ & $19.2-7.3$ & $18.9-12.3$ & $8.8-8.9$ & $4.8-18.7$ & $6.2-9.5$ \\
\hline 6 & $\begin{array}{l}\text { Highest } \\
\text { Lowest }\end{array}$ & $6.4-15.0$ & $-1.8-9.2$ & $0.9-8.5$ & $19.5-4.3$ & $19.7-2.1$ & $19.5-6.1$ & $8.1-15.8$ & $0.2-9.0$ & $0.7-6.9$ \\
\hline 7 & $\begin{array}{l}\text { Highest } \\
\text { Lowest }\end{array}$ & $6.0-17.7$ & $1.4-14.4$ & $2.2-11.1$ & $19.6-14.2$ & $19.1-14.4$ & $14.9-14.4$ & $8.2-17.8$ & $3.6-14.6$ & $1.4-10.4$ \\
\hline
\end{tabular}
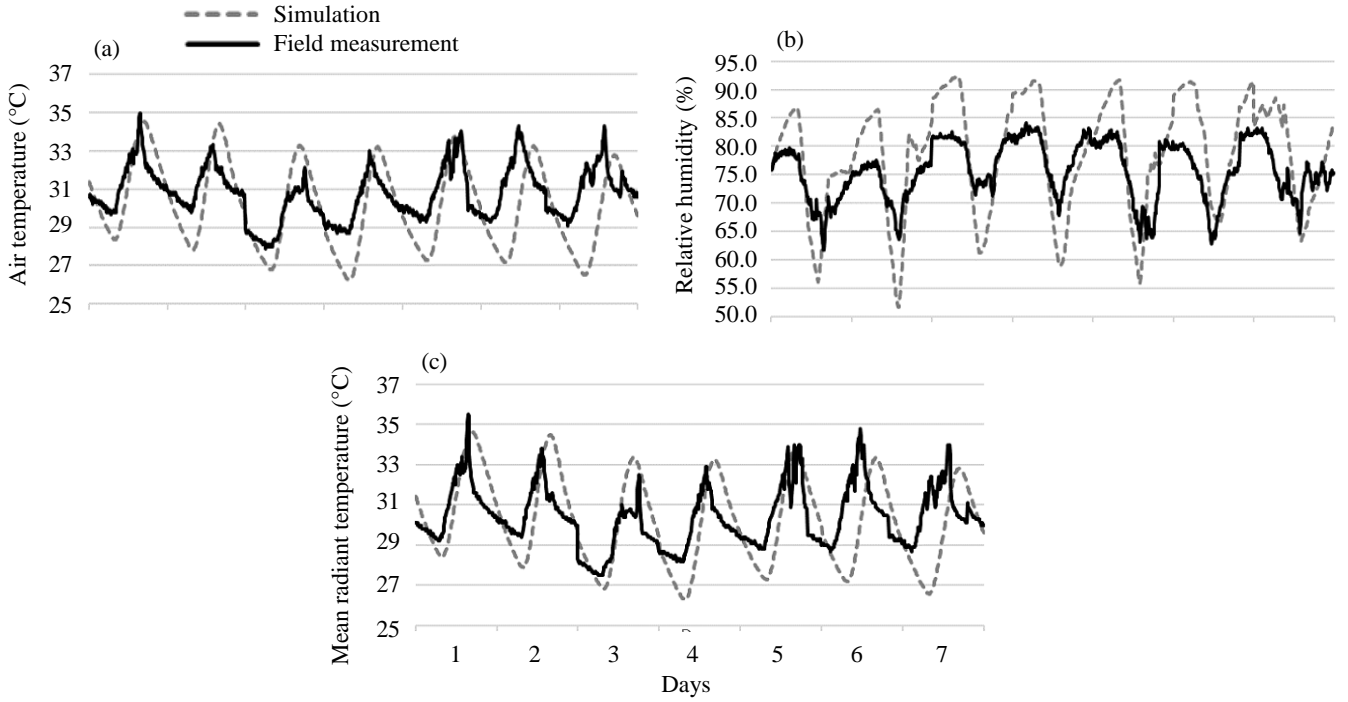

Fig. 4: Comparison between the on-field experiment and simulation for room 1 for indoor: a) Air temperature; b) Relative humidity and c) Mean radiant temperature

April 2017 at $1545 \mathrm{~h}$ while from the simulation data set, the lowest value of relative humidity recorded was $51.7 \%$ on the same day as the on-field experiment which was 24 April 2017 at $1355 \mathrm{~h}$. The discrepancy of the field experiment data and simulation is about $16.3 \%$ which falls within the acceptable range.

The on-field measurements of the indoor mean radiant temperature show that the highest mean radiant temperature in room 1 was $35.5^{\circ} \mathrm{C}$ on 23 April 2017 at $1535 \mathrm{~h}$ while the simulation results show that the highest mean radiant temperature in room 1 was $34.6^{\circ} \mathrm{C}$ on the same day at $1635 \mathrm{~h}$. The discrepancy of the highest mean radiant temperature recorded is $2.5 \%$ and the time difference is only $1 \mathrm{~h}$ which is considered acceptable, since, the percentage of difference is $<10-20 \%$. For the on-field experiments, the lowest mean radiant temperature in room 1 was $27.5^{\circ} \mathrm{C}$ at $0555 \mathrm{~h}$ on 27 April 2017 while the lowest simulated mean radiant temperature in room 1 was $26.3^{\circ} \mathrm{C}$ at $0735 \mathrm{~h}$ on 30 April 2017. The deviation of the IES-VE result of $4.3 \%$ is acceptable. The time differences between the two results is $<2 \mathrm{~h}$. Furthermore, the time recorded in the on-field experiment and simulation for the highest and lowest temperatures are similar. Figure 4 shows the comparison between the simulation and on-field measurement of the indoor air temperature, relative humidity and mean radiant temperature for room 1 .

It is clear that all the percentage differences for the three rooms for all the measured parameters are acceptable which are within the acceptable ranges as 
suggested by Maamari et al. (2006) (10-20\%). This means that the IES-VE Software can be considered as a precise tool for the simulation of the indoor air temperature, relative humidity and mean radiant temperature.

The results of the current study are strongly supported by the results of the previous related literatures. Leng et al. (2012) found that the IES-VE Software has an acceptable difference when compared with the on-field measurements for air temperature and relative humidity which did not exceed $20 \%$ (stand between $6.99-13.62 \%$ and $0.002-14.90 \%$, respectively). Nikpour et al. (2013) found that the differences between the simulation and on-field measurement was not more than $10 \%$. Therefore, the study concluded that the software has a sufficient accuracy to simulate heat gain in self-shading rooms. Supportively, the study of Azhar and Brown (2009) mentioned that the IES-VE Software is one of the favorable tools for the simulation performance analysis compared with the other green building simulation tools.

\section{CONCLUSION}

An investigation on thermal environment of a double-story house in hot humid climate in Malaysia was done using on-field measurement and simulation. This is a preliminary study for a future comprehensive simulation study in using the best materials to improve the indoor thermal environment and to reduce the discomfort hours inside the tested house that will contribute in reducing the energy usage for that building. The examination of simulating precision of air temperature and relative humidity using the IES-VE simulation software is an essential step to validate the software for the future research study. The validation results show that the differences between the on-field measurement and simulation results were acceptable (not more than $20 \%$ ). Therefore, the software has a sufficient accuracy to simulate air temperature, relative humidity and mean radiant temperature for double-story houses in Malaysia.

\section{ACKNOWLEDGEMENTS}

The researcher would like to acknowledge the Universiti Kebangsaan Malaysia (UKM) for supporting this research through University/Industry Research Grant (GUP-2017-111) and Dana Cabaran Perdana Grant (DCP-2017-008/5).

\section{REFERENCES}

Al-Mofleh, A., S. Taib, M.A. Mujeebu and W. Salah, 2009. Analysis of sectoral energy conservation in Malaysia. Energy- Int. J., 34: 733-739.
Annan, G., N. Ghaddar and K. Ghali, 2016. Natural ventilation in Beirut residential buildings for extended comfort hours. Intl. J. Sustainable Energy, 35: 9961013.

Anonymous, 2014. General climate of Malaysia. Malaysia Meteorological Department, Petaling Jaya, Malaysia.

Atmaca, I., O. Kaynakli and A. Yigit, 2007. Effects of radiant temperature on thermal comfort. Build. Environ., 42: 3210-3220.

Attia, S. and A. De Herde, 2011. Early design simulation tools for net zero energy buildings: A comparison of ten tools. Proceedings of the 12th Conference of International Building Performance Simulation Association, November 13-16, 2011, Sydney, Australia, pp: 94-101.

Azhar, S. and J. Brown, 2009. BIM for sustainability analyses. Int. J. Constr. Educ. Res., 5: 276-292.

Ben, H. and K. Steemers, 2014. Energy retrofit and occupant behaviour in protected housing: A case study of the Brunswick Centre in London. Energy Build., 80: 120-130.

Fanger, P.O., 1972. Thermal Comfort. McGraw Hill, New York, USA.,

Leng, P., M.H. Bin Ahmad, D.R. Ossen and M. Hamid, 2012. Investigation of integrated environmental solutions-virtual environment software accuracy for air temperature and relative humidity of the test room simulations. Proceedings of the International Annual Symposium on Sustainability Science and Management, July 9-11, 2012, Terengganu, Malaysia, pp: 1298-1305.

MEIH., 2015. Introduction to Malaysia energy information hub. Malaysia Energy Information Hub, Peninsular Malaysia. https://meih.st.gov.my/

MMD, 2010. General climate of Malaysia. Malaysian Meteorological Department, Petaling Jaya, Selangor. http://www.met.gov.my/index.php?option=com_co ntent\&task $=$ view\&id $=75 \&$ Itemid $=1089 \&$ limit $=1 \&$ lim itstart $=0 \&$ lang $=$ english.

Maamari, F., M. Andersen, J. de Boer, W.L. Carroll and D. Dumortier et al., 2006. Experimental validation of simulation methods for bi-directional transmission properties at the daylighting performance level. Energy Build., 38: 878-889.

Nikpour, M., M.Z. Kandar and E. Mousavi, 2013. Empirical validation of simulation software with experimental measurement of self-shading room in term of heat gain. World Appl. Sci. J., 21: 1200-1206.

Pollock, M., Y. Roderick, D. McEwan and C. Wheatley, 2009. Building simulation as an assisting tool in designing an energy efficient building: A case study. Eleventh International IBPSA Conference on Building Simulation 2009, July 27-30, 2009, Integrated Environmental Solutions Limited, Glascow, Scotland, pp: 1191-1198. 
Sulaiman, M.K.A.M., 2017. Cooling effect performance of indirect green facade on building in tropical climate of Malaysia. Ph.D Thesis, National University of Malaysia, Bangi, Malaysia.
UNDP., 2006. Achieving industrial energy efficiency in Malaysia. United Nations Development Programme, New York, USA. http://www.my.undp.org/ content/malaysia/en/home/library/environment_ene rgy/EEPub_IndustrialEnergyEfficiency.html 